\title{
A rare case of fatal venous and cerebral air embolism
}

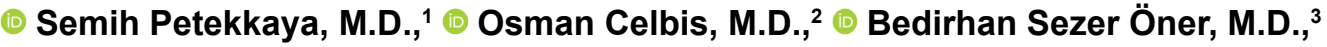 \\ (1) Ömer Turan, M.D., ${ }^{4} \odot$ Zeynep Yener, M.D. ${ }^{5}$
}

\author{
'Department of Forensic Medicine, Çanakkale Onsekiz Mart University Faculty of Medicine, Bolu-Turkey \\ ${ }^{2}$ Department of Forensic Medicine, Inönü University Faculty of Medicine, Malatya-Turkey \\ ${ }^{3}$ Department of Forensic Medicine, Amasya University Faculty of Medicine, Amasya-Turkey \\ ${ }^{4}$ Department of Forensic Medicine, İstanbul Medeniyet University Faculty of Medicine, İstanbul-Turkey \\ ${ }^{5}$ Council of Forensic Medicine, Yalova Branch Office, Yalova-Turkey
}

\begin{abstract}
A venous air embolism can occur as a result of circumstances that include blunt head or chest trauma, thoracentesis, arterial catheterization, neurosurgery, cardiac surgery, and Caisson disease. The formation of a venous air embolism requires an air source, interaction between the air source and the vessel, and a pressure gradient supporting air migration into the vessel. Air enters through the impaired venous structure and travels to the right side of the heart and the pulmonary arteries, and depending on the amount of air, may occasionally be fatal. This report is the description of the case of a 3-year-old child who developed a fatal venous and cerebral embolism during neurosurgery for the treatment of skull fractures with epidural and subdural bleeding due to blunt head and chest trauma resulting from a television falling on her.The pathophysiology of death and notes regarding the medico-legal autopsy procedure in such cases are discussed. Meticulous autopsy techniques must be used to determine the presence of an air embolism in cases of blunt trauma, especially in patients with blunt trauma to the head who die during neurosurgery, and possible future malpractice claims should be kept in mind.
\end{abstract}

Keywords: Craniotomy complications; frothy blood; medicolegal autopsy; venous air embolism.

\section{INTRODUCTION}

A venous air embolism is a rare, but potentially fatal, condition that can occur as a result of blunt head and chest trauma, thoracentesis, arterial catheterization, and especially during neurosurgical and cardiac surgery or cases of Caisson disease. ${ }^{[1-4]} A$ venous air embolism is also known as a pulmonary air embolism. Three conditions are required for the formation of a venous air embolism: the presence of an air source, interaction between the air source and a vessel, and a pressure gradient supporting air migration to the vessel. ${ }^{[2,5]}$ Air enters through a damaged vein wall and travels to the right side of the heart and the pulmonary arteries. The transition of at least $75 \mathrm{~cm}^{3}$ to $200-300 \mathrm{~cm}^{3}$ of air into the circulation is nec- essary for the development of a fatal venous air embolism. ${ }^{[6,7]}$ Low-volume venous air emboli occurring after minor intravenous interventions may reach the pulmonary circulation via the right atrium and the right ventricle, but they are generally asymptomatic. A large quantity of air entering the venous circulation, however, can cause death as a result of cardiovascular system blockage. ${ }^{[8]}$ In invasive surgical interventions, such as an adult cardiac bypass operation, the incidence of massive air embolism varies between $0.003 \%$ and $0.007 \%$, and various complications occur in half of the affected patients. ${ }^{[9]}$ According to DiMaio, ${ }^{[6]}$ air embolism occurs in $21 \%$ to $29 \%$ of all craniotomies and $40 \%$ of all occipital craniotomies, though

Cite this article as: Petekkaya S, Celbis O, Öner BS, Turhan Ö, Yener Z. A rare case of fatal venous and cerebral air embolism. Ulus Travma Acil Cerrahi Derg 2019;25:311-315.

Address for correspondence: Zeynep Yener, M.D.

İsmet Paşa Mah., Hakim Saadettin Berki Cad., Yalova Adliyesi, 5. Kat (Adli Tıp Şube Müdürlüğü) Yalova, Turkey.

Tel: +90 226 - 8142968 / 176 E-mail: drzeynepyener@hotmail.com 
it is rarely fatal. A venous air embolism may be seen in open cranial fractures resulting from blunt head trauma, especially if the fracture is displaced and multisegmental. ${ }^{[5]}$

Presently described is the case of a rare, fatal venous and cerebral air embolism that occurred during a neurosurgical operation on a 3-year-old girl who had blunt chest and head trauma as a result of a television falling upon her. Points to be considered in the medico-legal autopsy of such cases, and the pathophysiology and treatment of venous air embolism are discussed.

\section{CASE REPORT}

An unconscious 3-year-old girl was brought to the emergency department of a university hospital. A CRT television set had fallen on her while she was playing with the TV unit at her grandfather's house. On initial examination, her general condition was poor; she was unconscious and had a parietal cephalohematoma. The initial cranial computerized tomography (CT) scan showed displaced fractures in the right temporoparietooccipital bones and acute subdural-epidural hematoma in the same region. A follow-up CT revealed increased bleeding and an urgent operation to drain the subdural-epidural hematomas was performed.

She was placed on the operating table and her head was deviated to the left side for the neurosurgical operation. A fracture line initiating from the right temporal bone leading to the mastoid and occipital bone was observed. Bleeding from the posterior part of the fracture line was detected and this area was closed with bone wax and antihemorrhagic agents. A temporoparietooccipital craniotomy was performed by creating a burr hole in the occipital bone. Underneath the craniotomy defect, $2 \mathrm{~cm}$ of hemorrhagic fluid consistent with an epidural hematoma was observed and removed. When the dura was opened, additional hemorrhagic fluid compatible with an acute subdural hematoma was also removed. The brain pulsation was not clear. A sudden decrease in the end tidal carbon dioxide volume occurred. The patient was turned upside down. A drain was placed in the epidural space and suturing was performed. Upon the development of cardiac arrest following the suturing, cardiopulmonary resuscitation was performed; however, she didn't respond to resuscitation and was declared dead.
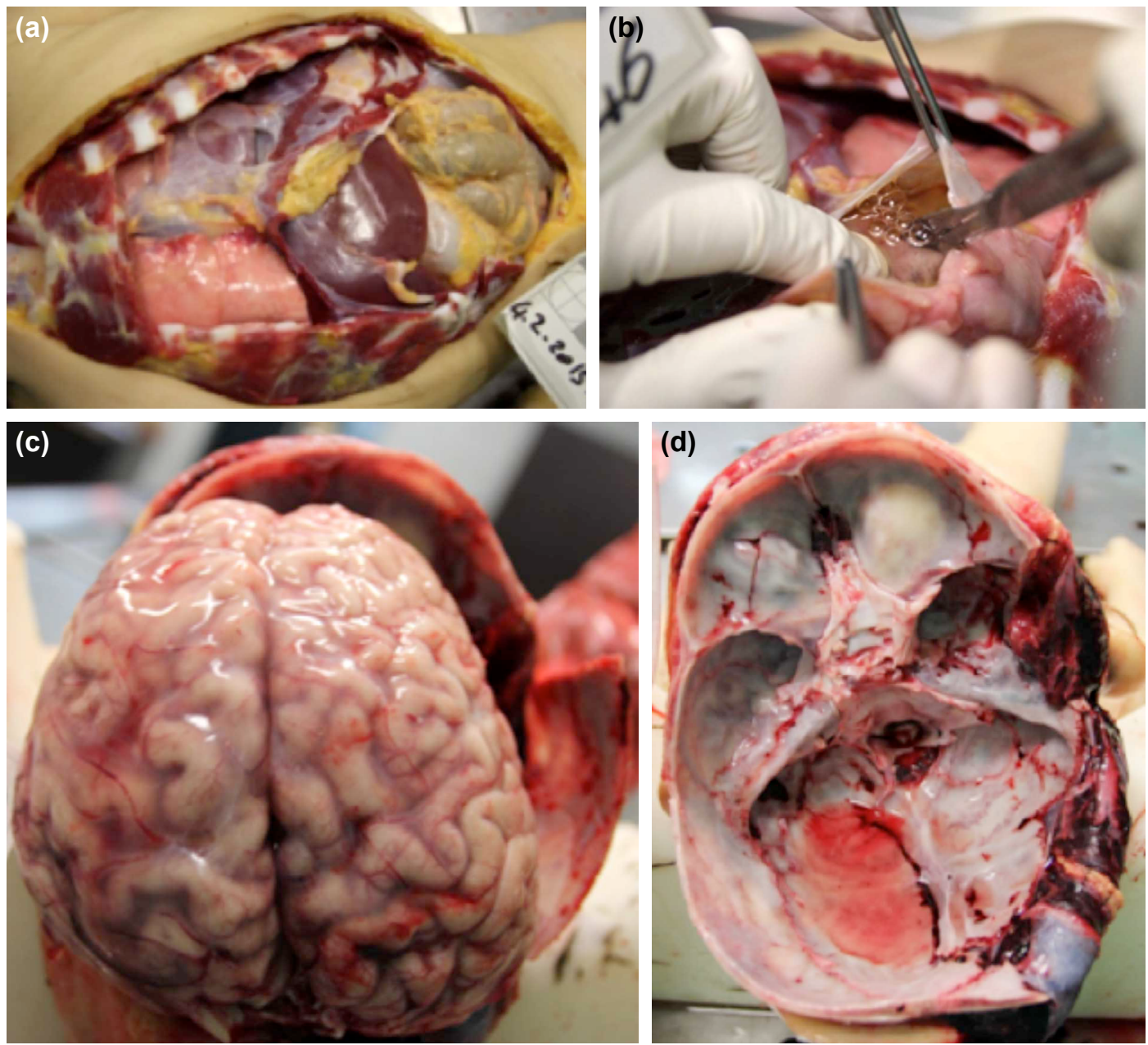

Figure 1. (a) The sternum was opened in a manner sufficient to preserve the upper third inside the chest. (b) Air bubbles in the heart. (c) A few air bubbles in the cerebral vessels. (d) Fractures in both orbital roofs, and the right temporal and occipital bones. 
Approximately 8 hours after her death, an autopsy was conducted to determine the cause of death. The medico-legal autopsy determined that the patient was a $12 \mathrm{~kg}, 91 \mathrm{~cm}$, female child, and that livor mortis and rigor mortis were present. No putrefaction sign or gas formation due to putrefaction was detected. A 22-cm, C-shaped, sutured surgical wound was noted on the temporoparietooccipital region, as well as left periorbital ecchymosis and needle marks on various regions of the body. In order to determine any presence of an air embolism, the thoracic cavity was opened in such a way as to preserve the upper one-third of the sternum inside the chest (Fig. Ia). The vessels of the thoracic inlet were preserved. The pericardium was opened and the inside was filled with water. The presence of air was investigated by puncturing the right ventricle with a scalpel. It was observed that there was a dense pocket of air bubbles (Fig. Ib). The main vessels of the heart were observed in the normal anatomical locations. There was frothy blood inside the heart. The foramen ovale was closed. Regions of petechial bleeding over the surface as well as parenchymal bleeding were observed in both lungs in cross-sections. An $8.5 \times 5 \mathrm{~cm}$-sized bone defect was observed on the right temporoparietooccipital region. Epidural bleeding was observed in the bilateral temporal and occipital regions. The brain had an edematous appearance. A few air bubbles were observed in the cerebral vessels (Fig. Ic). Subarachnoid bleeding in the lower part of the left frontal region and hemorrhagic infarct regions in the thalamus was observed. There were linear fractures in both orbital roofs, and in the right temporal and occipital bones (Fig. Id). Subarachnoid bleeding in the frontal lobe and fresh bleeding foci on the dura mater, as well as bleeding foci in both lungs were reported in the histopathological examination. No lethal or fatal toxic substances were detected in the toxicological examination. The conclusion was that the child's death occurred due to an air embolism.

\section{DISCUSSION}

A fatal embolism is a rare diagnosis in childhood medico-legal autopsies. Nonetheless, childhood traumas and medical interventions, such as surgery, vascular catheterization, and ventilation, may result in the transition of air into the arterial or venous circulation. ${ }^{[10]}$ The surgical procedures most frequently related to an air embolism are neurosurgical and cardiac surgery, epidural interventions, and umbilical venous catheterization. ${ }^{\left[{ }^{[1]}\right]}$ In our case, venous and cerebral air embolism occurred during a neurosurgical operation after blunt head trauma, which is the most common cause of air embolism.

In the postmortem period, a venous air embolism is diagnosed by the presence of air in either the vessel lumen or the chambers of the heart. ${ }^{[5]} \mathrm{A}$ cerebral air embolism is diagnosed based on the presence of air bubbles in the cerebral vascular system in autopsy. In order to diagnose a venous air embolism in suspected cases, the manubrium and upper ribs are preserved in order not to damage the main vessels, and the remaining parts of the sternum and ribs are dissected carefully. The pericardium is punctured and filled with water. The right and left ventricles are penetrated underwater and the presence of air bubbles is assessed. ${ }^{[2,12-14]}$ This technique can lead to false positive results in decaying corpses due to the gas formation related to putrefaction. ${ }^{[13]}$ In our case, the upper one-third of the sternum was preserved in order not to damage the main vessels. Afterwards, the pericardial sac was punctured and filled with water, and when the right ventricle was penetrated using a bistoury, an air bubble flow was observed. A diagnosis of venous air embolism was made. This technique is consistent with the literature and the accuracy of the diagnosis was increased by not creating an artifact, which may cause false positivity. Due to the absence of signs of decay in the body, false positivity as a result of decay-related gases was excluded.

Venous air embolism occurs most frequently during a neurosurgical operation in the context of a posterior fossa craniotomy performed in the sitting position as a result of the gradient created due to gravity. The incidence has been reported to be $76 \%$, though the rate of a fatal embolism is lower. Air enters through the venous sinuses during surgery and travels to the right side of the heart. ${ }^{[15,16]}$ Most vessels have thin walls, and when injured, the vessel lumen collapses due to external pressure exceeding the internal pressure. Thus, air transition and embolism are prevented. The dural sinuses have more rigid walls and preserve their luminal space even after injury. ${ }^{[5]}$ Our case had a displaced linear fracture in the bilateral orbital roofs, the right temporal bone, and occipital bones. Linear and displaced fracture lines, especially in the occipital region, cause tears and bleeding in the dural sinuses in this region. A craniotomy was performed in the side-lying position. An air embolism is less frequent in this position compared with the sitting position. In spite of blood and a blood clot being removed during the surgery, the injured dural sinuses retained sufficient rigid structure and negative air pressure to allow for an air embolism leading to subsequent death.

The pathophysiological effect of venous air embolism is correlated with the air volume that has accumulated in the right ventricle. Clinical findings may vary from focal neurological deficits to seizures, coma, loss of consciousness and diffuse encephalopathy in living cases ${ }^{[4]}$ An air embolism can also cause severe cardiovascular and respiratory dysfunction. A major embolism could lead to sudden cardiovascular collapse through complete output obstruction of the right ventricle, a decrease in pulmonary venous input, sudden right heart failure, a decrease in left ventricular preload, or a decrease in cardiac output. ${ }^{[1,12,14,15]}$ Right ventricular activity turns air and blood into frothy blood. ${ }^{[6,11]}$ During surgery, a sudden decrease in the end tidal $\mathrm{CO}_{2}$ volume and arterial oxygen saturation are important markers of an air embolism. ${ }^{[15]}$ In our case, a sudden decrease in the end tidal $\mathrm{CO}_{2}$ volume was considered a sign of a potential air embolism, thus the body was upside-down and cutaneous-subcutaneous suturing 
was performed in order to prevent more air from entering the circulation; however, sudden cardiac collapse occurred. The medico-legal autopsy revealed frothy blood due to right ventricular activity and an air embolism inside the heart, as expected. Clinical findings occur in living cases due to the amount of air entering the vein, the localization, and the air velocity. The findings may vary from focal neurological deficit to death, although asymptomatic cases may also be seen. ${ }^{[17]}$ An air or gas embolism can cause mechanical blockage of a vessel lumen with irritation and vascular endothelial damage. [18] Mechanical occlusion in a cerebral venous air embolism does not cause sudden arterial ischemia, but its interrelationship with the endothelium triggers neutrophil aggregation with beta2-integrin adhesion, and worsening venous stasis can potentially cause infarction. An ischemia-reperfusion mechanism to manage the inflammatory process further increases the damage. ${ }^{[19,20]}$ Treatment of an air embolism involves the delivery of emergency oxygen. The increased partial oxygen pressure will accelerate the absorption of gas and the air embolism will decrease in size. ${ }^{[21,22]}$ Hyperbaric oxygen therapy (HBOT) has been used to reduce the volume of intravascular gas bubbles in patients with a neurological deficit, though the clinical effects are still controversial. ${ }^{[20,23-26]}$ HBOT has 2 primary effects. First, increased atmospheric pressure will affect gas bubbles mechanically and their volume will decrease inversely with pressure. In addition, increased pressure helps the passage of gas and oxygen through the tissues and venous blood for elimination through the lungs. The second effect is significantly increased partial oxygen pressure. ${ }^{[22,27]}$ Satisfactory results were obtained after HBOT therapy was administered within the first 7 hours of a cerebral air embolism developing following cranial surgery. ${ }^{[28]}$

If air enters the arterial circulation directly through the pulmonary veins, even small amounts $(0.5-1 \mathrm{~mL})$ of air can be fatal. ${ }^{[20,29]}$ If the foramen ovale is closed, air transition from the venous to the arterial system may result either from pulmonary arteriovenous malformations or a physiological pulmonary shunt. A $1.5-3 \mathrm{~mL} / \mathrm{kg}$ air volume could also lead to over exceeding the filtration capacity of the lungs, thus resulting in embolism. ${ }^{[1]}$ Since the foramen ovale was closed in our case, a cerebral air embolism seems to have resulted from air transition to the arterial circulation from the lungs via the physiological shunts. The presence of a hemorrhagic infarct region in the thalamus, which requires more oxygen, as well as cerebral edema support our diagnosis. However, air can be an artifact in cerebral vessels when the skull is opened. In such cases, a cerebral air embolism diagnosis should be made after a detailed investigation of diagnosis-supporting signs.

Damage can be minimized by early diagnosis and treatment of air emboli, which have a high rate of mortality and morbidity. It should be considered that death may be due to air embolism in patients with blunt trauma findings, particularly to the head, who die during a neurosurgical operation. Precise medico-legal autopsy techniques that are sufficient to diagnose air embolization should be used to determine the presence of an air embolism, particularly given the possibility of a malpractice claim.

\section{Conflict of interest: None declared.}

\section{REFERENCES}

1. Roquero LP, Camelo-Piragua S, Schmidt C. Cerebral Air Embolism: A Clinical, Radiologic and Histopathologic Correlation. Am J Forensic Med Pathol 2016;37:241-4.

2. Opeskin K, Burke MP, Lynch M. Cerebral air embolism due to disconnection of a central venous catheter. J Clin Neurosci 1998;5:469-71.

3. Schlimp CJ, Loimer T, Rieger M, Lederer W, Schmidts MB. The potential of venous air embolism ascending retrograde to the brain. J Forensic Sci 2005;50:906-9.

4. Heckmann JG, Lang CJ, Kindler K, Huk W, Erbguth FJ, Neundörfer B. Neurologic manifestations of cerebral air embolism as a complication of central venous catheterization. Crit Care Med 2000;28:1621-5.

5. Adams V, Guidi C. Venous air embolism in homicidal blunt impact head trauma. Case reports. Am J Forensic Med Pathol 2001;22:322-6.

6. DiMaio VJ, DiMaio D. Forensic Pathology. 2nd ed. Boca Raton, FL: CRC Press; 2001:453-458.

7. Toung TJ, Rossberg MI, Hutchins GM. Volume of air in a lethal venous air embolism. Anesthesiology 2001;94:360-1.

8. Fujioka M, Niino D, Ito M, Matsuoka Y. Fatal paradoxical air embolism diagnosed by postmortem imaging and autopsy. J Forensic Sci 2012;57:1118-9.

9. Hammon JW, Hines MH. Extracorporeal circulation. In: Cohn LH, editor. Cardiac surgery in the adult. 4th ed. Chapter 12. New York: McGraw-Hill; 2012.

10. Byard RW. Fatal embolic events in childhood. J Forensic Leg Med 2013;20:1-5.

11. Sowell MW, Lovelady CL, Brogdon BG, Wecht CH. Infant death due to air embolism from peripheral venous infusion. J Forensic Sci 2007;52:183-8.

12. Saukko P, Knight B. Knight's Forensic Pathology. 4th ed. Boca Raton, FL: CRC Press; 2015. p. 347-9.

13. Saunders S, Kotecha D, Morgan B, Raj V, Rutty G. Demonstrating the origin of cardiac air embolism using post-mortem computed tomography; an illustrated case. Leg Med (Tokyo) 2011;13:79-82.

14. Novitsky YW, Mostafa G, Sing RF, Lipford E, Heniford BT. Fatal cardiac air embolism. Injury 2006;37:78-80.

15. Rice JC, Liebenberg L, Scholtz RP, Torr G. Fatal air embolism during endoresection of choroidal melanoma. Retin Cases Brief Rep 2014;8:127-9.

16. Spence NZ, Faloba K, Sonabend AM, Bruce JN, Anastasian ZH. Venous air embolus during scalp incision. J Clin Neurosci 2016;28:170-1.

17. Chang CC, Chao YK, Wu YM, Wong HF, Wong YC, Toh CH. Retrograde cerebral venous air embolism: A case report and review of literature. J Radiol Sci 2014;39:101-4.

18. Moon RE. Hyperbaric oxygen treatment for air or gas embolism. Undersea Hyperb Med 2014;41:159-66.

19. Buras JA, Reenstra WR. Endothelial-neutrophil interactions during ischemia and reperfusion injury: basic mechanisms of hyperbaric oxygen. Neurol Res 2007;29:127-31.

20. Muth CM, Shank ES. Gas embolism. N Engl J Med 2000;342:476-82.

21. Schlimp CJ, Bothma PA, Brodbeck AE. Cerebral venous air embolism: what is it and do we know how to deal with it properly? JAMA Neurol 2014;71:243.

22. Jain KK. Textbook of hyperbaric medicine. 6th ed. Springer. 2016.

23. Bothma PA, Schlimp CJ. II. Retrograde cerebral venous gas embolism: are we missing too many cases? Br J Anaesth 2014;112:401-4. 
24. Mirski MA, Lele AV, Fitzsimmons L, Toung TJ. Diagnosis and treatment of vascular air embolism. Anesthesiology 2007;106:164-77.

25. van Hulst RA, Klein J, Lachmann B. Gas embolism: pathophysiology and treatment. Clin Physiol Funct Imaging 2003;23:237-46.

26. Blanc P, Boussuges A, Henriette K, Sainty JM, Deleflie M. Iatrogenic cerebral air embolism: importance of an early hyperbaricoxygenation. Intensive Care Med 2002;28:559-63.

27. Berlot G, Rinaldi A, Moscheni M, Ferluga M, Rossini P. Uncommon occurences of air embolism: Description of cases and review of the litera- ture. Hindawi Case Reports in Critical Care 2018;1-7.

28. Lundborg M, Helseth E, Josefsen R, Braathen M, Skogen K, Ramm-Pettersen J. Hyperbaric oxygen therapy or air embolus in the cerebral venous sinuses after intracranial surgery: a case report. Acta Neurochirurgica 2018;160:1401-5.

29. Yadav S, Jain S, Aggarwal P, Gupta R. Systemic arterial air embolism: positive pressure ventilation can be fatal in a patient with blunt trauma. BMJ Case Rep 2013 Feb 15 [E-pub ahead of print], doi: 10.1136/bcr2012-008343.

\section{OLGU SUNUMU - ÖZET}

\section{Nadir görülen ölümcül venöz ve serebral hava embolisi \\ Dr. Semih Petekkaya, ${ }^{1}$ Dr. Osman Celbis, ${ }^{2}$ Dr. Bedirhan Sezer Öner, ${ }^{3}$ Dr. Ömer Turan, ${ }^{4}$ Dr. Zeynep Yener ${ }^{5}$}

${ }^{1}$ Çanakkale Onsekiz Mart Üniversitesi Tıp Fakültesi, Adli Tıp Anabilim Dalı, Çanakkale

2İnönü Üniversitesi Tıp Fakültesi, Adli Tıp Anabilim Dalı, Malatya

${ }^{3}$ Amasya Üniversitesi Tıp Fakültesi, Adli Tıp Anabilim Dalı, Amasya

${ }^{4}$ İstanbul Medeniyet Üniversites Tıp Fakültesi, Adli Tıp Anabilim Dalı, İstanbul

${ }^{5}$ Adli Tıp Kurumu, Yalova Şubesi, Yalova

Venöz hava embolisi kafa ve göğüs bölgelerine künt travma maruziyeti, torasentez, arteryel kateterizasyon gibi girişimler, vurgun hastalığı, kardiyak ve nöroşirürji cerrahi operasyonları sonrası ender olarak gelişebilmekte, gelişmesi halinde ise kardiyovasküler sistemde blokaj meydana getirerek ölüme yol açabilmektedir. Düşük miktarlardaki venöz hava embolileri sıklıkla asemptomatik olup, venöz hava embolisinin ölümcül olabilmesi için $75 \mathrm{~cm}^{3}$ ile 200-300 $\mathrm{cm}^{3}$ arasında hacme sahip havanın dolaşıma geçmesi gerekmektedir. Zedelenmiş sistemik ven yapısının içine giren hava dolaşım sisteminde önce sağ atriyuma sonra sırası ile sağ ventrikül ve pulmoner artere ulaşmaktadır. Çalışmamızda üzerine televizyon düşmesi sonucu künt göğüs ve kafa travması geçiren, yapılan incelemelerde kafatası kemiklerinde deplase kırıklar ve akut subdural-epidural hematom saptanması üzerine operasyona alınan, ancak operasyon sırasında ani kardiyak arrest gelişmesi üzerine öldüğü bildirilen üç yaşındaki kız çocuğu olgusu sunuldu. Küçük çocuğun yapılan medikolegal otopsisinde saptanan venöz ve serebral hava embolisi ile birlikte diğer otopsi bulguları sunularak, bu tür olgularda medikolegal otopsi uygulamasında dikkat edilmesi gereken noktaların ve gelişen ölümün patofizyolojisinin tartışılması amaçlanmaktadır.

Anahtar sözcükler: köpüklü kan; kraniotomi koplikasyonları; medikolegal otopsi; nöroşirurji; venöz hava embolisi.

Ulus Travma Acil Cerrahi Derg 2019;25(3):31 I-315 doi: 10.5505/tjtes.2018.5820 I 